\title{
Reform of Training Model for Applied Talents in Material Engineering Specialty under the Background of Civil Engineering
}

\author{
Tu-sheng HE \\ School of Civil Engineering \\ Shaoguan University \\ Shaoguan, 512005, Guangdong, China \\ Zai-bo LI \\ School of Civil Engineering \\ Shaoguan University \\ Shaoguan, 512005, Guangdong, China
}

\author{
Yang LIU \\ School of Civil Engineering \\ Shaoguan University \\ Shaoguan, 512005, Guangdong, China \\ San-yin ZHAO \\ School of Civil Engineering \\ Shaoguan University \\ Shaoguan, 512005, Guangdong, China
}

\author{
Xu-guang ZHAO \\ School of Civil Engineering \\ Shaoguan University \\ Shaoguan, 512005, Guangdong, China
}

\begin{abstract}
In order to promote the matching between talent cultivation mode of material engineering specialty and industry development, social demand, this paper analyzed the current situation and trend of material engineering specialty, with the help of the platform of civil engineering specialty, the material engineering specialty and civil engineering specialty (course + practice) was integrated, the talent cultivation model of applied material engineering specialty in local university was reformed according to optimize the teaching staff, construct the talent cultivation scheme, reform the training mode, strengthen the practical teaching, etc. The practice has proved that these reform measures have achieved good results and promote the development of the material specialty. At the same time, it can provide some reference for the development and reform of related specialties in similar universities.
\end{abstract}

Keywords-Local university; Applied type; Talent cultivation; Specialty reform

\section{INTRODUCTION}

The newly published Outline of National Medium and Long Term Educational Reform and Development Plan (2010-2020) clearly points out that one of the directions of higher education reform and development is to "optimize the structure and make its own characteristics" ${ }^{[1]}$. At present, the inorganic non-metallic materials engineering industry (cement, glass, ceramics, etc.) has basically completed the industrial upgrading featuring modern and large-scale production, and the demand for professional talents has stabilized. Inorganic non-metallic materials industry is in a critical period of industrial restructuring. There is a contradiction between supply and demand between the employment difficulties of college graduates and the recruitment difficulties of professionals urgently needed for industrial development. At the same time, with the rapid development of higher education in China for more than ten years, the traditional talent training mode has no longer adapted to the diversification of employment of undergraduates majoring in inorganic non-metallic materials engineering in China's colleges and universities ${ }^{[2]}$. Civil engineering is the main industry in China. After more than 30 years of great development, its materials are affected by the process of natural deterioration in the use process. In a fairly long period of time in the future, the existing civil engineering materials, structural testing, maintenance, reinforcement and other projects will increase day by day. However, from the perspective of professional knowledge, these jobs can be solved by non-civil single specialty, and there is still a large market for graduates of materials in civil engineering construction and engineering supervision ${ }^{[3]}$. Therefore, the above work will provide a huge employment and development space for material professionals and technicians.

\section{REFORM MEASURES}

In order to build a high-level application-oriented undergraduate specialty, this specialty has established a professional reform and construction Steering Committee with doctor, professor and senior enterprise technicians and management experts as the main body. According to the actual needs of Applied Talents in the development reality and planning of material industry in the province and region, the committee provides guidance for the formulation of talent training programs and the construction of talent training modes and is responsible for supervising and guaranteeing the implementation of various aspects of professional construction. 
So as to ensure the expected effect of the comprehensive reform of the specialty, and make the talent training more local characteristics and advantages. The specific construction plan is as follows:

\section{A. Construction of Teachers}

1) Introduction and optimization of Teachers.

In the comprehensive reform of the specialty, the construction of the teaching staff should be put in the first place. In view of the current reality of the faculty composition of this specialty, we should focus on introducing young and middle-aged teachers with doctoral degrees, especially young and middle-aged academic/disciplinary leaders with outstanding achievements. Employing enterprise engineering and technical personnel and management experts with rich engineering practice experience as part-time professors/teachers, to engage in undergraduate teaching and guide young teachers of their own specialty, to form a group of external teachers with stable personnel, enthusiastic education and high professional quality.

\section{2) Team building of teaching and scientific research}

Teaching and scientific research team building is an important measure to improve the level of teachers. Through the guidance and support of relevant policies and taking the opportunity of undertaking major teaching quality projects, we should build a high-level teaching team with excellent teachers/famous teachers as the leader, focusing on building a high-level teaching team with scientific teachers, engineering teachers and applied teachers as its characteristics and relevant curriculum groups as its teaching objects. Taking the opportunity of undertaking major scientific research projects, we should actively carry out joint scientific research between schools and enterprises, set up academic backbone as the leader, and strive to build a high-level scientific research team. Teachers are encouraged to study for a doctoral degree in universities at home and abroad, to be visiting scholars and postdoctoral students, to conduct academic exchanges and to carry out cooperative research. Formulating on-the-job training plan for teachers' teaching skills; dispatching full-time teachers to participate in various teaching seminars and training courses, participating in on-the-job training and assessment of professional skills, focusing on improving their engineering practice ability and level ${ }^{[4]}$; organizing regular training of external teachers, participating in teaching and research activities, focusing on improving their teaching skills and teaching level.

\section{B. Optimization of Talents Training Program}

According to the national economic situation and the potential demand of industrial development for the knowledge structure, ability structure and professional ethics of Applied Talents in this major, as well as the forecast of the employment situation of graduates in recent years, the optimization of the training program of applied talents in this major is guided by the basic requirements of national engineering education certification, with the ultimate goal of improving the employment rate and quality of students' employment. Specific optimization contents are as follows:

1) Promoting the Integration of Professional Talents and Civil Engineering Industry in Knowledge Structure.

On the premise of guaranteeing the guiding opinions of the state on the construction of materials specialty, this specialty will open 2 to 5 courses related to civil engineering, encourage students to take part-time courses in civil engineering, and promote the integration of talents and knowledge structure of civil engineering industry. In TABLE I.

TABLE I. NeW Civil ENGINEERING COURSES IN THIS SPECIALTY

\begin{tabular}{|c|c|c|c|}
\hline Number & Course name & $\begin{array}{l}\text { Class } \\
\text { hour }\end{array}$ & Target description \\
\hline 1 & Housing Architecture & 32 & $\begin{array}{l}\begin{array}{l}\text { This paper introduces the basic function composition, principle and construction requirement of } \\
\text { the house. }\end{array} \\
\end{array}$ \\
\hline 2 & $\begin{array}{l}\text { Basic Concepts of Concrete } \\
\text { Structures }\end{array}$ & 48 & The concept and design method of mechanical properties of concrete members are introduced. \\
\hline 3 & Design of Masonry Structure & 32 & $\begin{array}{l}\text { This paper introduces the mechanical performance and design principle and method of the } \\
\text { masonry structure. }\end{array}$ \\
\hline 4 & Foundation Engineering & 32 & This paper introduces the basic principle of foundation and foundation treatment method. \\
\hline 5 & $\begin{array}{l}\text { Civil Engineering Construction } \\
\text { Technology }\end{array}$ & 32 & $\begin{array}{c}\text { This paper introduces the basic technology, organization and management technology of } \\
\text { Engineering construction. }\end{array}$ \\
\hline 6 & Green building materials & 22 & $\begin{array}{c}\text { New building materials and green energy-saving and environmental protection construction } \\
\text { technology are introduced. }\end{array}$ \\
\hline
\end{tabular}

2) Modular teaching, Preliminary Realization of Directional Training of Students.

In order to highlight the school-running characteristics of market demand-oriented and student-centered, this specialty is based on the credit system and establishes a curriculum system consisting of general platform courses, professional basic core courses, professional core courses and elective module courses in different directions. According to the three principles of students' personal wishes, learning potential and social needs, it is planned to gradually expand from the current single training specification to two subdivisional directions (in Table II for details), so as to ensure that the talent training program is closely linked with the needs of enterprises for applied technical talents. 
TABLE II. DESIGN OF TRAINING ORIENTATION FOR THIS SPECIALTY

\begin{tabular}{|c|l|l|l|}
\hline Number & Training direction & Description of main characteristics & $\begin{array}{c}\text { The proportion of } \\
\text { students in diversion } \\
\text { schemes }\end{array}$ \\
\hline 1 & $\begin{array}{l}\text { Research and } \\
\text { Development }\end{array}$ & $\begin{array}{l}\text { Postgraduate entrance examination with } \\
\text { certain research and development ability } \\
\text { and postgraduate entrance potential }\end{array}$ & $\begin{array}{l}\text { Enter professional theory, deepen curriculum module learning, } \\
\text { participate in teachers' scientific research and students' } \\
\text { independent scientific and technological innovation research }\end{array}$ \\
\hline 2 & $\begin{array}{l}\text { Production } \\
\text { Management and } \\
\text { Marketing }\end{array}$ & $\begin{array}{l}\text { Master engineering professional skills } \\
\text { and engineering management knowledge }\end{array}$ & $\begin{array}{l}\text { Enter the module study of professional skills courses, special } \\
\text { skills training and competition, professional certification, } \\
\text { students' independent scientific and technological innovation } \\
\text { research }\end{array}$ \\
\hline
\end{tabular}

\section{Teaching Method Reform}

Implementing the training mode of after-class tutorial system and optimizing the educational environment in an all-round way.

At present, there are many practical problems in College students, such as lack of social experience, unclear learning objectives, lack of initiative in independent learning and alienation between teachers and students. Therefore, on the premise of improving the quality of classroom teaching, the focus of the work of optimizing the educational environment in an all-round way is to carry out the training mode of after-class tutorial system ${ }^{[5]}$. Its training mode takes scientific research, product development, skill training, professional competition and postgraduate entrance examination as an opportunity. Teachers guide and guide students to participate in the above-mentioned work. Teachers' main duty is to establish a correct outlook on life and values, expand students' horizons, stimulate students' learning motivation, enlighten students' thinking and improve students' professional quality through their own words and deeds. At the same time, to guide and solve students' ideological and life problems. It will enable students to get all-round and full-time training in school, and promote the seamless integration of classroom knowledge imparting and after-school education.

\section{Strengthen Practical Teaching}

\section{1) Infrastructure Construction of Professional Practice} Teaching.

With the help of special funds from schools, the construction of professional practical teaching infrastructure will be accelerated. For the experiment of professional basic courses, it is mainly to strengthen the standardized construction of infrastructure, and for the practical teaching of professional experiments, it is mainly through the purchase of a number of key large-scale instruments and equipment. And we optimize and integrate the existing instruments and equipment to provide hardware support for the construction of practical teaching system which is closely linked with theoretical teaching, from simple to complex, from single to comprehensive and progressive.

2) Make full use of various social resources to improve the quality of practical teaching.

Market-oriented, full use of various social resources to cultivate applied talents, including: a) Deepening the cooperation with the production, teaching and research bases, and exploring the innovative mode of two-way training of talents in cooperation between schools and enterprises ${ }^{[6]}$.
Contents include: joint guidance of professional practice training; joint establishment of research and development centers or laboratories between schools and enterprises, according to the topics provided by enterprises, students carry out scientific and technological innovation research and project development; and graduation thesis (design) topics. Fully realize the optimal allocation and sharing of resources in school teaching and enterprise personnel training. b) Employing enterprise engineering and technical personnel and management experts with rich engineering practice experience as part-time professional teachers, to serve as instructors of Undergraduates' experimental courses, curriculum design, graduation thesis (design), professional practice and professional skills training, so as to achieve the optimal allocation of human resources in the experimental and practical teaching of this specialty.

\section{BENEFICIAL EFFECTS}

Preliminary completion of on-the-job full-time teachers as the main body and external teachers as the support of the composition of dual professional teachers, and make the professional teachers more balanced and optimized in terms of professional title, educational background and age structure, especially in terms of individual competence orientation; and realize the whole process of teaching and guidance from professional classroom teaching to experimental practice teaching by external senior experts.

The formulation and optimization of a personnel training program for materials specialty were completed. Among them: The total teaching hours should not exceed 2600 class hours, and the credit system should be fully implemented. The breadth of theoretical teaching content was expanded and two characteristic elective course modules were constructed in professional courses (Material Engineering + Civil Engineering).

Three new professional practice bases have been added, relying on the current practice teaching bases and external teachers, to construct and improve the professional teaching and education system based on school-enterprise cooperation, school as the main body, enterprise and society's full participation, with the development characteristics of local undergraduate colleges and universities, which provides strong support for the realization of professional training objectives.

The training mode of the after-school tutorial system was fully implemented. There were more than $50 \%$ of students engaged in after-class research projects, such as "innovative 
experiment plan for college students", "climbing plan", "independent scientific research projects (scientific and technological innovation activities) and participate in teachers' scientific research projects.

\section{CONCLUSION}

Through the reform of personnel training mode, the orientation of students' training in this specialty is more accurate and the characteristics are more distinct. Which enable the students to master the basic knowledge of inorganic non-metallic materials engineering specialty and the necessary professional knowledge of civil engineering specialty, and train engineering and technical personnel for material and civil engineering development and testing, maintenance, reinforcement, civil engineering construction organization and management. At the same time, it can provide some reference for the development and reform of related specialties in similar universities.

\section{ACKNOWLEDGMENT}

Foundation projects: Higher education reform project of Guangdong province in 2016, "Reform of training mode of applied talents for inorganic and non-metallic materials engineering specialty under the background of civil engineering" (Guangdong Higher Education Letter [2016]
236-475); Shaoguan University educational reform research project (SYJY20151653, SYJY20161750, SYJY20171811).

\section{REFERENCE}

[1] Ping Xu. Research on talent training mode for local colleges and universities [J]. Experimental Technology and Management. vol. 32, pp 164-167, Jun 2015. (In Chinese)

[2] Xiong Zhang, Si-feng Liu, Zheng-hong Yang. The exploration and practice of the talent cultivation mode of civil engineering materials for "made in China 2025" [J]. Research and Exploration in Laboratory. vol 37, pp 268-271, Mar 2018. (In Chinese)

[3] Jian Xie. A probe into the mode of training compound applied talents in local university [J]. Theory and Practice of Education. vol 37, pp 3-5, 2017. (In Chinese)

[4] Zhi-wei Hou, Zhong Chen. A probe into training mode of applied machinery majors in universities [J]. Theory and Practice of Education. vol 38, pp 12-14, 2018. (In Chinese)

[5] Hai-jun Zhang, Shu-lan Zhang, Xiao-li Qi, etc. Exploration and practice of personnel training mode on innovation entrepreneurship education in local universities and colleges [J]. Research and Exploration in Laboratory. vol 36, pp 222-225+254, Aug 2017. (In Chinese)

[6] Guang-xiang Yang, Feng Yang, Jian-hua Qu. Cooperation of university-local government for training innovatively application-oriented talents [J]. Research and Exploration in Laboratory. vol 37, pp 269-271+275, Feb, 2018. (In Chinese) 